\title{
Advanced Microbubbles as a Multifunctional Platform Combining Imaging and Therapy
}

\author{
Xianwei $\mathrm{Ni}^{\dagger}{ }^{\dagger}$ Jinmin Ye, Liping Wang, Shunlong Xu, Chunpeng Zou ${ }^{\dagger}$, Yan Yang * and Zhe Liu * \\ Department of Ultrasonic Diagnosis, The Second Affiliated Hospital \& Yuying Children's Hospital of Wenzhou \\ Medical University, Wenzhou 325027, China; nxwstc2014@163.com (X.N.); 15888781301@163.com (J.Y.); \\ wliping0226@163.com (L.W.); xus17009@126.com (S.X.); chpzou@126.com (C.Z.) \\ * Correspondence: yang25yan@126.com (Y.Y.); liuzhe@wibe.ac.cn (Z.L.); Tel.: +86-577-8801-7517 (Y.Y. \& Z.L.) \\ + These authors contributed equally to this work.
}

Academic Editor: Kohji Masuda

Received: 6 October 2016; Accepted: 11 November 2016; Published: 21 November 2016

\begin{abstract}
Microbubbles as traditional ultrasound contrast agents have seen tremendous developments and bio-applications in the past decades. Due to their outstanding performance, advanced microbubbles as a multifunctional platform combining both imaging and therapy have been increasingly attracting attention. Associated with ultrasound-mediated stimuli, targeting drug transportation with high precision can be established and, as a consequence, a synergistic treatment strategy may prevail, which implies a bright perspective for this brand-new technology. This perspective article will summarize the latest developments on the advanced microbubbles, and review their emerging biomedical applications for the vast community of both applied ultrasound and functional ultrasound-based materials.
\end{abstract}

Keywords: ultrasound; microbubbles; multifunctional; UTMD; targeted therapy

\section{Introduction}

Ultrasound (US) is widely used in clinics and has become a traditional diagnostic strategy for various diseases due to outstanding profiles such as low cost, ionization-free radiation, real-time availability, portable operation, etc. [1]. US imaging has been applied in vast fields from abdomen or superficial lesions to heart and intracavitary examinations. In order to enhance the image contrast and resolution, ultrasound contrast agents (UCAs) are always used in clinical diagnosis. Gramiak and Shah first reported UCAs in echocardiography in 1968 [2]. The saline injection was administered in heart which dramatically improved the quality of ultrasonography due to the bubbles in the contrast medium. In this sense, contrast-enhanced ultrasonography (CEUS) has been investigated in the last decades and has become a routine method to diagnose diseases with comparable contrast enhancement with computed tomography (CT) or magnetic resonance imaging (MRI) [3]. Thus, US exhibits great potential as a powerful diagnostic tool to detect pathological behavior with prominent precision and efficiency.

Moreover, UCAs have been applied not only for diagnosis but also for therapy such as thrombolysis and drug delivery. UCAs such as microbubbles have proved effective in curing intravascular thrombus [4]. Kaneko et al. disclosed that high-intensity focused ultrasound associated with UCAs could be used in the liver treatment [5]. The microbubbles could be destroyed by ultrasound, and the permeability of cell membranes could be increased, enabling them to perform drug/gene delivery $[6,7]$. Therefore, UCAs present a great opportunity not only as a powerful diagnostic tool but also as a multifunctional platform to serve therapeutic purposes in clinics. Further perspectives by using microbubbles (MBs) as UCAs and drug/gene delivery carriers will imply emerging developments 
and even broader applications in assisting disease treatments with this versatile platform. At present, several kinds of commercial UCAs have been approved in clinical applications (Table 1).

Levovist and Albunex can be used in cardiovascular imaging; however, because of their disadvantages of bad enhancement effect and short duration, Levovist and Albunex gradually exited the contrast media market around 2000. SonoVue is mainly used to characterize liver lesions. The use of SonoVue to assess the early response to anti-angiogenetic drugs in cancer chemotherapy has been studied. With promising results, wider studies are ongoing. Optison was much more effective at killing cells than other agents, and may be the best US microbubble contrast agent for gene therapy [8]. The UCAs whose gas core contain $\mathrm{C}_{3} \mathrm{~F}_{8}$ are considered the best material for microvascular imaging.

Table 1. Frequently used commercial UCAs (ultrasound contrast agents) in clinics.

\begin{tabular}{|c|c|c|c|c|c|c|}
\hline UCAs & Albunex & Optison & Levovist & SonoVue & Definity & Sonazoid \\
\hline Manufacturer & $\begin{array}{l}\text { Molecular } \\
\text { Biosystems }\end{array}$ & Amersham & Schering AG. & Bracco Diagnostics & $\begin{array}{l}\text { Bristol-Myers } \\
\text { Squibb Medical } \\
\text { Imaging }\end{array}$ & Nycomed/Amersham \\
\hline Composition & Albumin & Albumin & Lipids/Galactose & Lipids & Lipid/Surfactant & Lipid \\
\hline Gas core & Air & $\mathrm{C}_{3} \mathrm{~F}_{8}$ & Air & $\mathrm{SF}_{6}$ & $\mathrm{C}_{3} \mathrm{~F}_{8}$ & $\mathrm{C}_{4} \mathrm{~F}_{10}$ \\
\hline Size & $4.3 \mu \mathrm{m}$ & $2-4.5 \mu \mathrm{m}$ & $2-4 \mu \mathrm{m}$ & $2-3 \mu \mathrm{m}$ & $1.1-3.3 \mu \mathrm{m}$ & $2-2.8 \mu \mathrm{m}$ \\
\hline Application & $\begin{array}{l}\text { Cardiovascular } \\
\text { imaging }\end{array}$ & $\begin{array}{l}\text { Cardiovascular } \\
\text { imaging, } \\
\text { myocardial } \\
\text { perfusion imaging, } \\
\text { thermoablation of } \\
\text { tumors, gene } \\
\text { therapy }\end{array}$ & $\begin{array}{c}\text { Cardiovascular } \\
\text { imaging, general } \\
\text { vascular imaging, } \\
\text { abdominal } \\
\text { visceral imaging, } \\
\text { sonothrombolysis }\end{array}$ & $\begin{array}{l}\text { Cardiovascular } \\
\text { imaging, general } \\
\text { vascular imaging, } \\
\text { tumor imaging, } \\
\text { carotid plaque } \\
\text { imaging, ultrasonic } \\
\text { positioning, gene } \\
\text { therapy, drug delivery, } \\
\text { sonothrombolysis }\end{array}$ & $\begin{array}{l}\text { Cardiovascular } \\
\text { imaging, } \\
\text { myocardial } \\
\text { perfusion imaging, } \\
\text { general vascular } \\
\text { imaging, tumor } \\
\text { imaging, gene } \\
\text { delivery, } \\
\text { thrombolysis }\end{array}$ & $\begin{array}{l}\text { Tumor imaging } \\
\text { Guiding treatment } \\
\text { and assessing } \\
\text { treatment response }\end{array}$ \\
\hline Reference & {$[9,10]$} & {$[8,11-13]$} & [14-17] & [18-25] & {$[11,26-30]$} & {$[31,32]$} \\
\hline
\end{tabular}

Over the past few years, ultrasound molecular imaging (UMI) and ultrasound molecular therapy (UMT) have made leaps toward everlasting developments in both preclinical and clinical investigations to detect the disease processes at the molecular or cellular level in a visualizable manner. With the introduction of novel specific biomarker-targeted UCAs, early-stage detection and therapy will be achieved. At present, these studies mainly focus on the fields of tumor detection, inflammation, cardiovascular diseases, blood-brain barrier (BBB) disruption, brain metastasis, thrombolysis and related interdisciplinary sections (Figure 1).

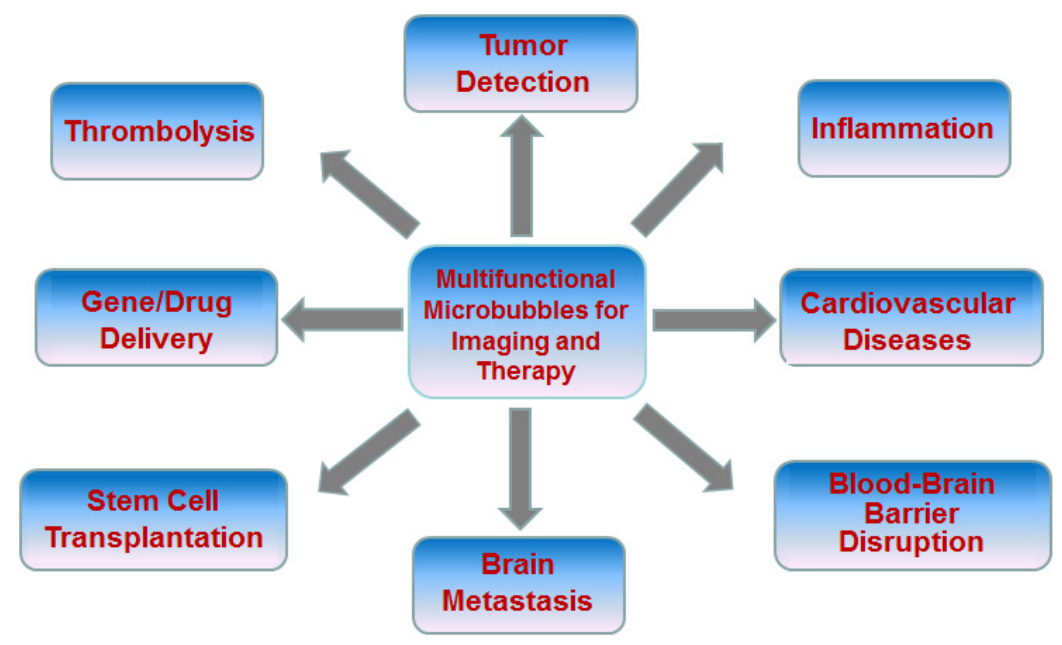

Figure 1. Arena of UCAs (ultrasound contrast agents) as a multifunctional platform combining imaging and therapy. 


\section{Advanced Microbubbles for Imaging and Therapy}

\subsection{Tumor Detection}

Although MBs can improve ultrasound image resolution, there is no specific targeting capability for them to differentiate between normal and cancerous tissues. Thus, MBs are always constructed with the attachment to specific binding ligands such as peptides, affibodies, antibodies, etc. to be able to actively target the tumor areas. With the targeted MBs anchoring at the cancerous regions, ultrasonic echo signals can be significantly enhanced which leads to early diagnosis of cancers. In the process of tumor angiogenesis, the integrin family is a main factor of mediating cell and extracellular matrix adhesion. The relationship between integrin $\alpha v \beta 3$ and tumor angiogenesis is the most attractive to researchers and has become a hot topic. Integrin $\alpha v \beta 3$ receptor is overexpressed on the surface of a variety of malignant tumors and endothelial cells of tumor tissue angiogenesis, otherwise not expressed in mature vascular endothelial cells and the vast majority of normal organ systems. Its overexpression provides molecular targets as imaging probes and could be used in ultrasound to detect angiogenesis. Yan developed iRGD (internalizing arginine-glycine-aspartate)-lipopeptide-based $\alpha \mathrm{v} \beta 3$ integrin-targeted MBs $(1.36 \pm 0.89,1.24 \pm 0.74,1.09 \pm 0.61 \mu \mathrm{m})$ as non-invasive molecular imaging probes to tumor angiogenesis [33]. The binding specificity for endothelial cells was significantly stronger $(p<0.01)$ under in vitro static and dynamic conditions. US images revealed strong contrast enhancement within the mice bearing $4 \mathrm{~T} 1$ breast tumors compared with the control MBs. In addition to integrins, vascular endothelial growth factor receptors (VEGFRs) are regarded as another kind of specific biomarker of neoangiogenesis. Nascimento designed VEGFR2-targeted MBs in combination with $40 \mathrm{MHz}$ endoluminal ultrasound biomicroscopy (eUBM) to detect colon tumors [34]. Wei developed VEGFR2-targeted MBs in an orthotopic model of renal cell carcinoma (RCC) to image angiogenesis. Compared with MBs conjugated to an isotype control antibody $(\mathrm{MBC})$ or naked microbubbles $(\mathrm{MBN})$, the duration of contrast enhancement of MBs conjugated to anti-VEGFR2 antibody (MBV) demonstrated prolonged contrast intensity within the tumor. Furthermore, the contrast intensity for MBV was significantly higher in the tumors than in normal parenchyma $(p<0.01)$ [35]. Pillai purified phospholipid-PEG2000-peptide which has nanomolar affinity for VEGFR2, and incorporated it into gas-filled microbubbles. In vivo experiments showed the VEGFR2-targeted microbubbles (BR55) greatly provided imaging of angiogenesis [36] (Figure 2). In a further study, Sorace established triple-targeted MBs with antibodies against mouse $\alpha v \beta 3$ integrin, P-selectin and VEGFR2 for evaluating the early response to antiangiogenic therapy. Tumor-bearing mice were injected with the multi-targeted microbubbles for contrast-enhanced US imaging and microbubble accumulation was calculated by destruction-replenishment techniques and time-intensity curve analysis. It was found that the vascularity of breast cancer decreased within Day 1 of bevacizumab injection by real-time monitoring of molecular US imaging, and further reduction of vascularity was detected by day 3 [37]. Bachawal found that vascular expression of B7H3 was selectively and significantly higher in breast cancer tissues through an IHC analysis of 248 human breast specimens. Then a kind of B7H3-targeted MB was prepared to identify that the US imaging signal increased significantly in breast cancer tissues in vivo. These findings concluded that the use of B7H3-targeted MBs can be a useful tool to improve the diagnostic accuracy of breast cancer detection in patients [38]. US imaging can also be applied to monitor the tumor angiogenesis during tumor development [39]. Hu et al. conjugated RGD peptides to the MB shell via biotin-avidin linkage. These RGD-MBs showed significantly higher adhesion to $\alpha v \beta 3$-expressing endothelial cells compared to the controls. In vivo experiments verified that the quantitative acoustic intensity in Hep2-tumor xenografts showed significantly higher in small tumors $(19.89 \pm 2.49)$ than those in medium $(11.25 \pm 2.23)$ and large tumors $(3.38 \pm 0.67)$. The results concluded that RGD-MBs enabled non-invasive in vivo visualization of tumor angiogenesis during tumor growth in Hep2 cancers [40]. In addition to the targeted microbubbles have showed above to assess the tumor angiogenesis, the other targeted UCAs applied in animal experiments have been summarized in Table 2. 


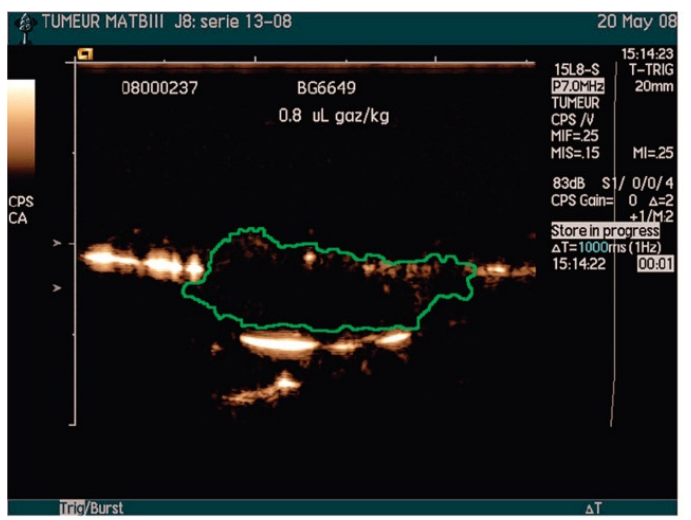

A
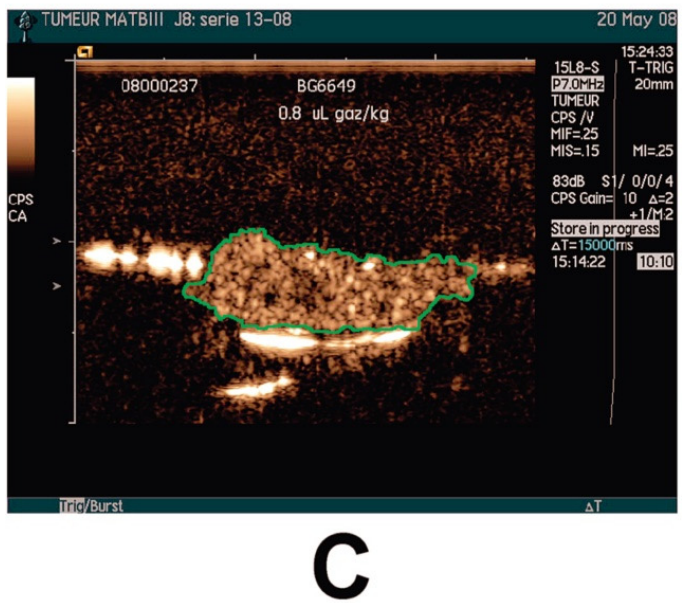

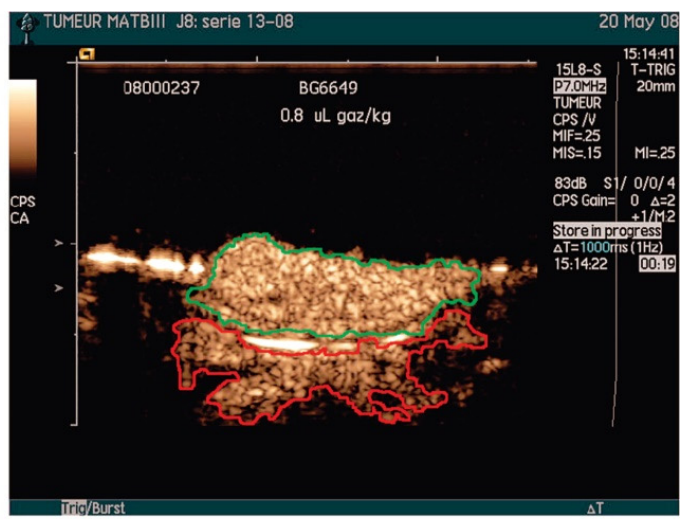

B

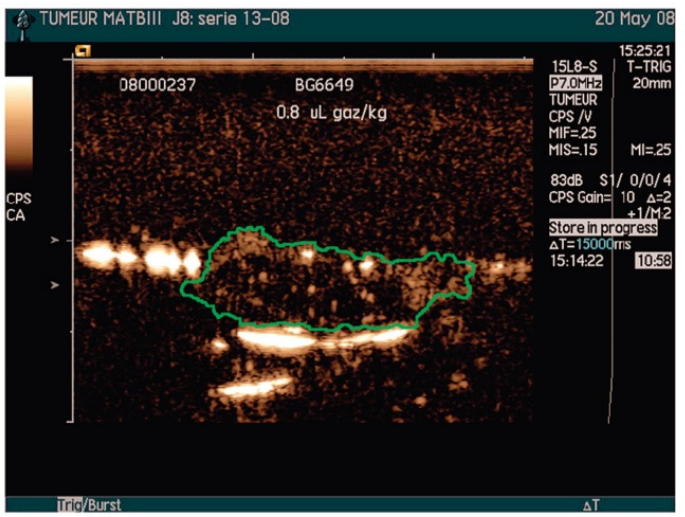

D

Figure 2. Ultrasound images of MAT B III tumors in CPS (Contrast Pulse Sequencing)mode. Green outline implied tumor; red outline implied nontumoral vasculature. (A) Before injection of the VEGFR2-targeted microbubbles (BR55); (B) At $20 \mathrm{~s}$ after injection of BR55 (peak intensity), the tumor vasculature and nontumoral vasculature shows hyperechoic; (C) At 10 min after injection of BR55, only the VEGFR2-targeted microbubbles are adherent to the tumor vasculature; (D) At $11 \mathrm{~min}$, the microbubbles in the tumor were cleared and residual circulating bubbles were waiting for refilling of the tumor. Note: Copyright 2010, American Chemical Society.

Microsized bubbles can only be used for intravascular imaging, but nano-scaled bubbles can be carried out of vasculature for tumor tissue imaging. Mai prepared biocompatible chitosan-VC lipid nanobubbles (NBs) to conjugate Cy5.5 as ultrasound-fluorescence dual-modal contrast agents for tumor imaging in mouse tumor model injected with murine liver cancer cells H22. Their sizes range between 400 and $800 \mathrm{~nm}$, and both in vitro and in vivo studies indicated that they had high accumulation in tumors [41]. Kim et al. prepared $\mathrm{CaCO}_{3}$ nanoparticles as ultrasound enhanced-contrast agents (UECAs) for tumor ultrasound imaging. In vivo experiment showed this nanosized UECA had a significant US contrast enhancement at the tumor site and was excreted out quickly [42] (Figure 3). Yang fabricated NBs $(478.2 \pm 29.7 \mathrm{~nm}$ in diameter, PDI $0.164 \pm 0.044)$ via a thin-film hydration method, and successfully attached the NBs with biotinylated anti-ErbB2 affibody, which has high affinity and specificity for the HER2 overexpressed in some breast cancer tumors [43]. It was found that these NB-affibody conjugates were promising candidates for HER2-positive tumors and applicable for quantitative diagnosis. A novel kind of nanoparticle containing folate-PEG-chitosan and perfluorooctyl bromide cores was prepared [44]. Not only excellent stability and biocompatibility were confirmed, but also an increased amount of targeted nanoparticles was observed accumulated in hepatocellular carcinoma cells. 
(A)

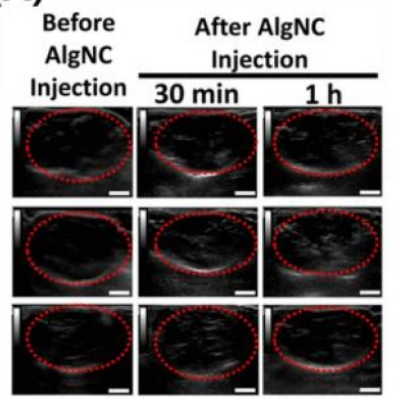

(B)

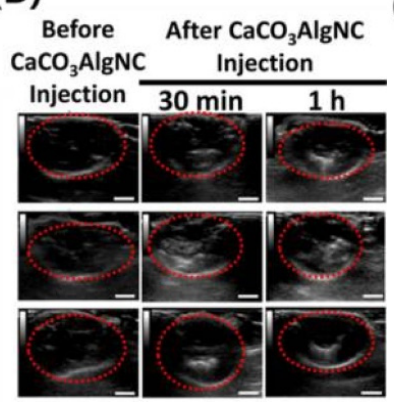

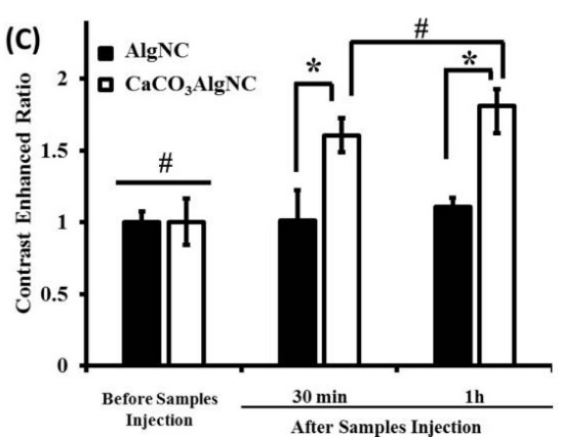

Figure 3. Comparison of before and after i.v (intravenously) injection of (A) AlgNC; and (B) $\mathrm{CaCO}_{3}$-AlgNC in vivo ultrasound imaging of tumors showed in the red outline; (C) Significant differences between contrast-enhanced ratio of $\mathrm{CaCO}_{3}-\mathrm{AlgNC}$ and $\mathrm{AlgNC}$ post-injection. ${ }^{*}, p<0.05$, and \#, $p>0.05$. Note: Copyright 2016, American Chemical Society. Abbrevation: NC: nanocarrier.

Table 2. Assessment tumor angiogenesis with different targeted microbubbles (MBs).

\begin{tabular}{|c|c|c|c|}
\hline Target & Ligand & Tumor Model & Reference \\
\hline VEGFR2/KDR & Heterodimeric peptide (BR55) & Colon carcinoma & [45] \\
\hline VEGFR2 & Heterodimeric peptide (BR55) & $\begin{array}{c}\text { Mammary carcinoma, Breast cancer, } \\
\text { Prostate adenocarcinoma, } \\
\text { Renal cell carcinoma }\end{array}$ & [46-48] \\
\hline VEGFR2 & Antibody & $\begin{array}{c}\text { Breast cancer, Pancreatic cancer, } \\
\text { Squamous cell carcinoma, } \\
\text { Angiosarcoma (SVR), Glioma (C6) }\end{array}$ & [49-51] \\
\hline$\alpha v \beta 3$ & Cyclic RGD peptide & Breast cancer & [33] \\
\hline$\alpha v \beta 3$ & RGD & Squamous cell carcinoma & [52] \\
\hline$\alpha v \beta 3$ & Echistatin & Glioma & [53] \\
\hline$\alpha v \beta 3$ & Knottin & Ovarian cancer & [54] \\
\hline Endoglin (CD105) & Antibody & Pancreatic cancer & [50] \\
\hline SFRP2 & Antibody & Angiosarcoma (SVR) & [39] \\
\hline $\begin{array}{l}\text { VEGFR2, } \alpha \text { V } \beta 3, \text { Endoglin } \\
(\mathrm{CD} 105)\end{array}$ & Antibody & $\begin{array}{l}\text { Subcutaneous cancers (breast, } \\
\text { ovarian, pancreatic cancer) }\end{array}$ & [55] \\
\hline VEGFR2, $\alpha \mathrm{V} \beta 3$, P-selectin & Antibody & Breast cancer & [37] \\
\hline$\alpha \mathrm{V} \beta 3$, ICAM-1 & Antibody & Prostate cancer & [56] \\
\hline VEGFR2 $+\alpha v \beta 3$ & Antibody & Ovarian cancer & [57] \\
\hline VEGFR $2+\alpha \mathrm{v} \beta 3+$ ICAM1 & Antibody & Human MDA-MB-231 breast cancer & [58] \\
\hline CRPPR, ATWLPPR & Antibody & Breast cancer & [59] \\
\hline
\end{tabular}

\subsection{Inflammation}

The pathophysiology of inflammation is a series of molecular signals generated by the inflammatory responses that turn the leukocytes into the inflamed tissues. Leukocytes firmly adhere to the vascular endothelial cell wall before they transmigrate from the blood circulation into inflamed tissues. P-selectin expresses rapidly on activated endothelial cells upon inflammation occurs. The endothelial cells also overexpress E-selectin, and leucocytes can overexpress L-selectin, intercellular adhesion molecule1 (ICAM-1) and vascular cell adhesion molecule1 (VCAM-1) which can mediate the adhesion of leucocytes and endothelial cells at the inflammatory lesions. Therefore, P-, E- and L-selectin, ICAM-1 and VCAM-1 can be used as specific biomarkers of inflammation to evaluate their occurrence at an early stage. Molecular US imaging has been successfully applied to inflammations including inflammatory bowel diseases, myocardial ischemia, arthrosclerosis, and rejection in cardiac transplantation. Bettinger developed P-selectin glycoprotein-functionalized MBs (MBrPSGL-Ig) [60]. The adhesion efficiency of 
MBrPSGL-Ig constructs under static or flow conditions and molecular imaging studies were performed in the rat inflammatory model by intravenous injection of MBs with monitoring the accumulation of targeted MBs in the muscle. It proved that they could interact specifically and efficiently with E- and P-selectin at the surface of inflamed endothelial cells. The echo signals measured with MBrPSGL-Ig in the inflamed muscles was 20-fold higher compared with control MBs. The in vivo adhesion of MBrPSGL-Ig was 2- and 7-fold higher compared with P-selectin or E-selectin-specific MBs, respectively. Wang developed dual-targeted MBs (MBSelectin) for P- and E-selectin-specific inflammation in a murine acute colitis model [61]. Small animal imaging experiments showed that MB-selectin had strong attachment to both human and mouse P- and E-selectin and significantly increased US signals in mice. They concluded with US imaging inflammation in a murine acute colitis model could be quantitatively detected and the natural pathway of leukocyte recruitment in inflammatory tissues has been revealed. Machtaler et al. assessed acute inflammation with dual P- and E-selectin-targeted US imaging [62]. Mice at different stages of inflammation were imaged following intravenous injection of P- and E-selectin-targeted MBs. It showed the US signals increased due to induction of acute inflammation at days 0,1 , and 3, and the percentage of P- and E-selectin-positive vessels increased in immunofluorescence. This method has been consolidated to accurately measure acute inflammation in a clinically relevant murine model of chronic IBD.

The molecular US imaging also can monitor the early inflammatory effects following acute kidney injury with P-selectin-targeted and VCAM-1-targeted MBs, which has been developed by Hoyt et al. [63]. Non-invasive imaging for detecting acute cardiac transplant rejection was considered impossible in the past. Weller conjugated anti-rat ICAM-1 to lipid-based MBs (MBICAM) to detect acute rejection of cardiac transplantation. MBICAM was found to adhere to inflammatory endothelial cells in vitro and in vivo; moreover, myocardial video intensity from adhered MBICAM was found significantly higher, thereby implying that ICAM-1-targeted MBs may offer a non-invasive US imaging methodology for the successful detection of acute cardiac transplant rejection [64].

\subsection{Cardiovascular Diseases}

It is difficult to diagnose the thrombus in the blood vessels or heart cavity since in some cases a small thrombus is hard to locate. In recent years, a variety of thrombus-targeted MBs have been engineered to provide a new perspective for emboli detection by means of US imaging. Hagisawa developed the perfluorocarbon-containing bubble liposomes (BL) with RGD peptides, which bind to activate platelet glycoprotein IIb/IIIa complexes to enhance signals in thrombus US imaging [65]. The targeted BL were mixed with whole blood in vitro, and injected into rabbits with acute thrombotic occlusions in the ilio-femoral artery in in vivo experiments and used a 7.5-9 MHz linear transducer and a conventional ultrasound machine to image the thrombi. The results showed that these targeted MBs could markedly enhance the image contrast in thrombus imaging and may be useful for diagnosing acute thrombotic vessel occlusion. Ultrasound of arterial thrombi has immense potential, but the high-shear arterial flow limited effective binding of MBs to the thrombi. To overcome this obstacle, cyclic peptide with a sequence of Arg-Gly-Asp-D-Phe-Cys was fabricated and proved that they had much higher binding affinity and selectivity to the glycoprotein IIb/IIIa receptors than its linear counterparts. They are thus likely to be the optimal targeted probes for imaging arterial thrombi with US modality. Hu also constructed novel MBs conjugated to detect arterial thrombi, which had greater GP IIb/IIIa-targeted binding capability under all shear stress conditions [66]. The echogenicity of the platelet-rich thrombus was enhanced in vitro and the intensity of the abdominal aortic thrombi showed 3.2-fold higher than the control in vivo. With this technique, ultrasound provides a strategy to diagnose the acute coronary syndrome in patients without clear symptoms or electrocardiographic features. Hyvelin applied clinically translationable dual P- and E-selectin-targeted MBs to detect transient myocardial ischemia [67]. The results showed high US imaging enhancement within the ischemic area compared with remote myocardial tissues in myocardial ischemia/reperfusion rats. In the meantime, it has been demonstrated that these dual selectin-targeted MBs in transient myocardial ischemia 
provide reliable detection of transient myocardial ischemic events (late-phase enhancement persisted 5 and $24 \mathrm{~h}$ post reperfusion) without inducing ventricle dysfunction and myocardial necrosis.

\subsection{Blood-Brain Barrier Disruption}

The blood-brain barrier (BBB) is a special capillary endothelial system with tight junctions and metabolic barriers. It can keep the internal central nervous system (CNS) stabilized by preventing the macromolecular agents from transportating freely, but can also hinder neuro-active substances and drugs (such as nervous peptides, proteins and chemotherapeutic drugs) from curing brain diseases by BBB opening. Since 2001, Hynynen et al. found that the intravenous injection of MBs before focused ultrasound (FUS) irradiation can significantly enhance the opening of BBB, and the BBB could remain intact within $24 \mathrm{~h}$ without causing any neuronal injuries [68]. Therefore, the study of focused ultrasound on opening BBB as a novel therapeutic method associated with functional MBs has implied a new era in this regard [69] (Figure 4). Mooney determined that transcranial FUS techniques could be used to transiently open the BBB and stimulate hippocampal neurogenesis [70]. They also found that FUS at a pressure of $\sim 0.78 \mathrm{MPa}$ along with MBs could promote hippocampal neurogenesis and efficiently increase the BBB permeability.
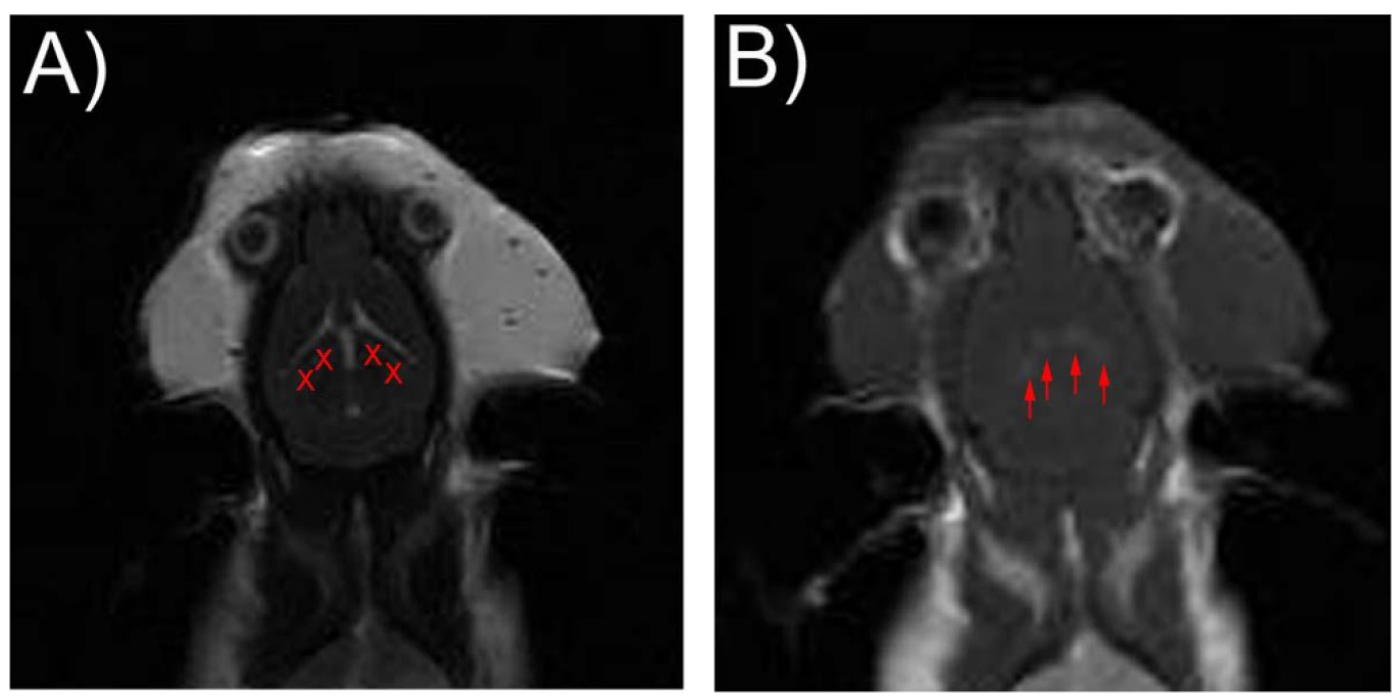

Figure 4. BBB (blood-brain barrier) disruption in MRI (magnetic resonance imaging). (A) Four spots in the dorsal hippocampus were chosen marked with $\times$ in T2-weighted images. (B) Following sonication, in T1-weighted images, four hyperintense spots (marked with red arrow) illustrated BBB disruption with injection of gadolinium contrast agents $(0.2 \mathrm{~mL} / \mathrm{kg}$; Omniscan, GE Healthcare, Milwaukee, WI, USA). Notes: Copyright 2013, American Chemical Society. Abbrevation: BBB: blood-brain barrier.

The ultrasound-induced BBB disruption plays an increasingly key role in the drug/gene delivery to the CNS. US in the presence of MBs transiently and reversibly opens the BBB in rodents and humans, thereby providing a time window for boosting drug delivery into the brain. Kobus investigated the feasibility of FUS in combination with MBs to improve the response by temporary disruption of the BBB. They prepared rat models inoculated with HER2-positive cells derived from a brain metastasis of a breast cancer patient (MDA-MB-361) and received trastuzumab and pertuzumab combined with six weekly sessions of BBB disruption using focused ultrasound. Finally, the results demonstrated that the application of FUS to disrupt BBB combined with antibody therapy could inhibit the brain metastasis [71]. Lelu et al. analyzed the mechanisms that govern ultrasound-mediated opening of the $\mathrm{BBB}$, and disclosed that porcine brain endothelial cells (PBEC) have low permeability for both small molecules and proteins. Their studies indicated that stable cavitations in presence of SonoVue MBs might have a more pronounced impact on cell permeability as compared to inertial cavitation [72]. 
Fan proposed the use of folate-conjugated DNA-loaded cationic MBs (FCMBs) to increase the efficiency of gene delivery to brain tumors and optimized the FUS parameters for FCMB-enhanced gene delivery by cell experiments. It indicated that FCMBs show better gene transfection efficiency than MBs without folate conjugation [73].

Numerous experiments have confirmed that the BBB disruption has an expansibility significance in the CNS. Samiotaki found that the use of FUS combined with MBs can promote the nerve growth factor into the substantia nigra striatum with peripheral intravenous administration [74]. At $1 \mathrm{~h}$ after administration, the biological activity of the nerve growth factor in the substantia nigra striatum was significantly higher than the direct administration without FUS, and the activation of the downstream signal pathway of nerve growth factor was detected in the neurons. Lin further developed a new delivery protocol by conjugating gene-loaded liposomes with MBs. They successfully improved gene-delivery efficiency and applied it to Parkinson's disease (PD) treatment. This study demonstrated that the gene-loaded MBs with FUS-induced BBB opening was an effective approach and might be a therapeutic strategy for neurodegenerative diseases such as Parkinson's, Alzheimer's and Huntington's diseases [75]. Leinenga applied repeated scanning ultrasound (SUS) for treatments of the mouse brain to remove $\mathrm{Ab}$ which is implicated in the pathogenesis of Alzheimer's disease [76]. Their findings suggest that repeated SUS treatment could induce microglia to effectively cleanse $\mathrm{Ab}$ and may be potentially promising for Alzheimer's therapy. Aryal et al. further tested the impact of periodic FUS in combination with liposomal doxorubicin (DOX) in a rat glioma tumor [77]. They found a pronounced improvement in median survival time by $100 \%$ of rats that received FUS + DOX compared to rats only treated with DOX or FUS, and approximately $75 \%$ of tumors appeared almost completely cured in the FUS + DOX group. Multiple sessions using FUS to enhance the delivery of liposomal doxorubicin had a prominent effect in a rat glioma model.

The study on BBB opening is not confined to animal experiments, but has been translated to clinical trials to some extent. A first clinical test on US-assisted chemotherapy for malignant brain tumors has been carried out at the University of Toronto in 2015 [78]. Carpentier et al. also applied Sonocloud as an US device for treatment with carboplatinin patients with recurrent glioblastoma (GBM) in a clinical trial. The BBB opening using Sonocloud combined with monthly systemic microbubble injection proved to be safe and well tolerated in patients, and acceptable treatments have been effective according to current clinical data [79].

\subsection{Thrombolysis}

Thrombotic arterial occlusion is the major cause of acute cardiovascular syndromes such as stroke and myocardial infarction. Exposing the thrombus to MBs in the presence of US mediation can facilitate the thrombus disruption, and thus become a powerful methodology for thromboembolic diseases. Multiple studies have confirmed that US is capable of accelerating thrombolysis. In the 1970s, Trubestein first suggested applying US to destroy thrombi. Artificial human blood clots were exposed to $170 \mathrm{kHz}$ of US and urokinase, and albumin MBs were introduced to trigger the acceleration of thrombolysis. Follow-up studies were focused on the evaluation of the thrombolytic efficacy between desmoteplase (DSPA) combining with therapeutic US and rt-PA treatment. The results showed that DSPA combined with 2-MHz US significantly accelerated rt-PA lysis (32.8\% vs. $26.5 \%$ ) [80-82]. Schleicher determined the effect of BR38 and Sonovue on MB-enhanced sonothrombolysis in a rat stroke model and concluded that it may be a therapeutic strategy for patients with continuous hypoperfusion of the ischemic territory [83]. Petit also investigated the impact of MB-mediated sonothrombolysis on the fibrin network of clots [84]. They showed that the combination rt-PA + US + MB enhanced both the diameter loss $(0.77 \pm 0.07 \mathrm{~mm})$ and fibrin degradation $(50.3 \% \pm 2.4 \%)$ compared to rt-PA alone $(0.24 \pm 0.01 \mathrm{~mm}$ and $36.5 \% \pm 1.7 \%)$, which implied a strong synergistic effect. It was also found that sonothrombolysis with MB greatly improves rt-PA-mediated clot lysis and fibrin degradation. On this basis, Lu injected platelet- or erythrocyte-rich microthrombi in intracarotid artery to induce the acute ischemic stroke rat model. In comparison, the effect of US + MB + rt-PA groups was the highest in 
cerebral infarction reduction and neurological deficits improvement. All these studies confirmed that MB-mediated sonothrombolysis has high effectiveness and good outcome in microemboli-induced acute ischemic strokes through dissolution of the microthrombi [85].

Rapid dissolution and reduction of thrombus is the principal goal for patients with intermediate- and high-risk pulmonary embolism (PE). By analysis with 53 consecutive patients with intermediate-risk PE treated with US-assisted catheter-directed thrombolysis at Brigham and Women's Hospital from 2010 to 2014, there was a reduction of 7.2 and $11.4 \mathrm{mmHg}$ in mean and systolic pulmonary artery pressure after treatments [86].

\subsection{Drug/Gene Delivery}

The technology of ultrasound-targeted microbubble destruction (UTMD) has become one of the most promising strategies for the targeted delivery of drugs/genes, which can protect the drugs/genes from capture or destruction by the external environment, and achieve US-triggered targeted drug/gene delivery to the lesions. Studies show that the efficiency of UTMD is mainly determined by the pressure, duration of US exposure and MB concentration [87]. Zhao et al. used the heparinized MBs carrying acidic fibroblast growth factor (aFGF) in combination with UTMD to study rat models with myocardial infarction, and found that the technique of UTMD could effectively facilitate aFGF delivery to the myocardium and therefore improve cardiac function recovery [88]. Fuji injected stem cell factor (SCF) and stromal cell-derived factor (SDF-1 $\alpha$ ) into rats with myocardial infarction with the assistance of UTMD. The results showed that the delivery of SCF and SDF- $1 \alpha$ to the infarcted myocardium recruited progenitor cells after treatments, and led to increased vascular density and enhanced tissue repair [89]. Liao et al. disclosed US-MB-mediated diclofenac delivery to treat adjuvant-induced rheumatoid arthritis (RA) in rats. By combining US and MBs, the skin permeability could be increased which thereby enhanced the delivery of diclofenac sodium gel and also inhibited inflammation of the tissues surrounding the arthritic ankle. Color Doppler-mode US imaging revealed that US-MB combinatory treatments induced a rapid reduction in synovial neoangiogenesis in the arthritic area [90]. Xiang et al. further optimized the UTMD technique by improving the in vivo transfection efficiency of the enhanced green fluorescent protein (EGFP) plasmid in the synovial pannus in an antigen-induced arthritis rabbit model. The EGFP expression in the synovial pannus of the US + MBs + plasmid group was significantly higher than that of the other four groups. This validated that UTMD has become a safe and effective non-viral gene transfection procedure for arthritis therapy [91]. Zhang's group developed simvastatin (Sim)-loaded polymeric MBs for targeting inflamed vascular endothelium to serve the diagnosis and treatment of atherosclerosis. This gas-filled MBs for drug delivery demonstrated promises to provide a stable acoustic enhancement and effectively identify atherosclerotic areas of plaque within the ventral aorta of rabbits [92]. Chertok modified the surface of DNA nanocarriers with heparin to inhibit passive gene transfer in both the target and the off-target tissues, and selectively activated heparin-inhibited gene to transfer at the target site by using UTMD [93]. They observed that the engraftment reduced off-target gene expression in the liver by more than 700-fold compared to the non-heparinized PEGylated liposomes; tumor-directed UTMD increased gene transfer with heparin-modified nanoplexes by more than 10-fold (Figure 5). 

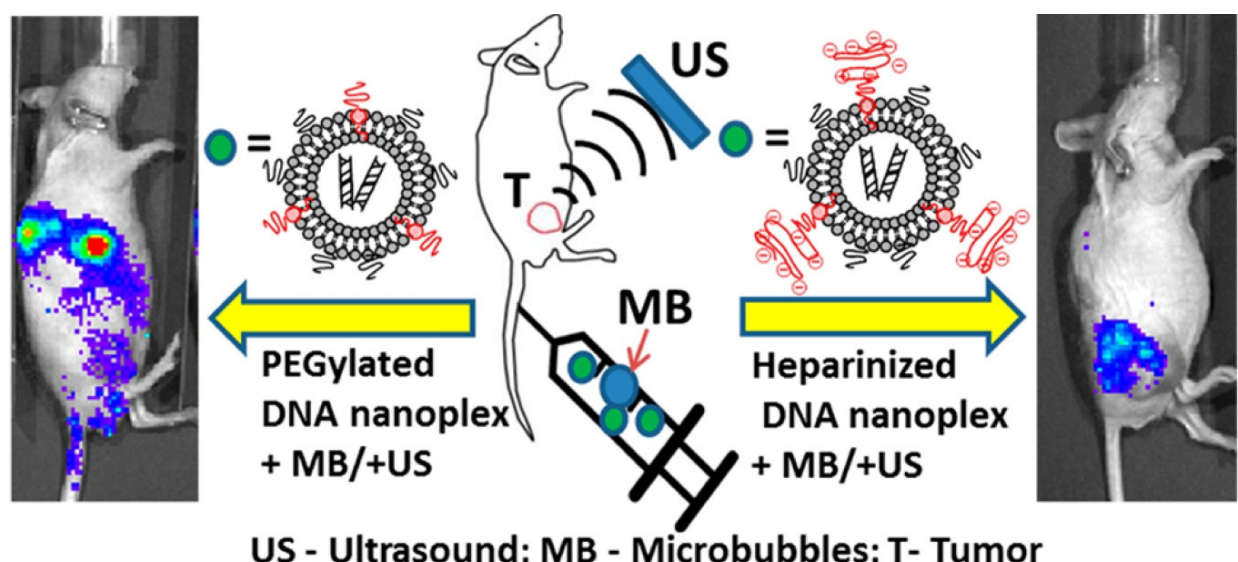

Figure 5. Intravenous administration of DNAlipHep and DNAlipPEG in tumor bearing mice with UTMD (ultrasound-targeted microbubble destruction). Notes: Copyright 2016, American Chemical Society.

Not only can UTMD increase the delivery of drugs/genes, but the ultrasound itself can also improve the efficiency of delivery. In a study, Chung designed a novel ${ }^{68}$ Ga-labeled integrin $\alpha 2 \beta 1$-targeted PET tracer ${ }^{68} \mathrm{Ga}-N O T A-P E G 4-c y c l o ~(G D G E A y K) ~\left({ }^{68} \mathrm{Ga}-\mathrm{A} 2 \mathrm{~B} 1\right)$ and uptake was higher in subcutaneous U87MG tumor-bearing athymic mice [94]. Then they found that with or without tracer integration of microbubbles, ${ }^{68} \mathrm{Ga}-\mathrm{A} 2 \mathrm{~B} 1$ tumor uptake could be improved in combination with focus ultrasound (Figure 6).

${ }^{68} \mathrm{Ga}-\mathrm{A} 2 \mathrm{~B} 1$

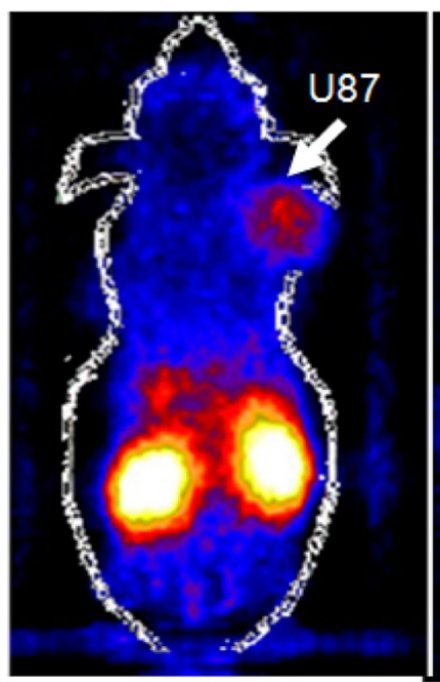

${ }^{68} \mathrm{Ga}-\mathrm{A} 2 \mathrm{~B} 1+\mathrm{FUS}+\mathrm{MBS}$

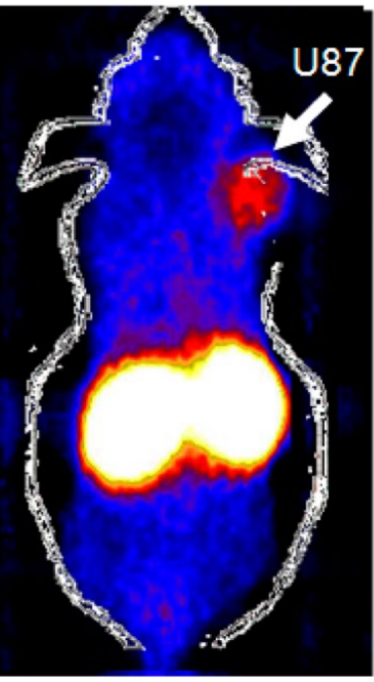

${ }^{68} \mathrm{Ga}-\mathrm{A} 2 \mathrm{~B} 1-\mathrm{MBs}+\mathrm{FUS}$

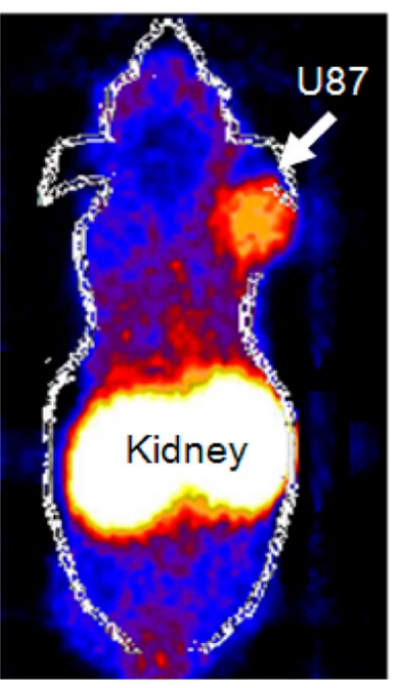

$5 \% \mathrm{ID} / \mathrm{g}$

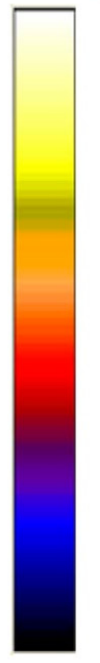

$0 \% \mathrm{ID} / \mathrm{g}$

Figure 6. Using focus ultrasound the tumor uptake of ${ }^{68} \mathrm{Ga}-\mathrm{A} 2 \mathrm{~B} 1$ was significantly higher compared with control. Notes: Copyright 2014, American Chemical Society. Abbrevation: Glioblastoma, integrin $\alpha 2 \beta 1$, PET imaging, focus ultrasound.

The UTMD technology does not only increase the localized drug concentration at the targeted organs or tissues, but it also reduces the side effects of systemic drugs. This has been proved by Chen et al. who prepared hydrogen sulfide-loaded MBs (hs-MBs) with different H2S/C3F8 ratios, and US-targeted hs-MB destruction was applied in a rodent model of myocardial ischemia-reperfusion injury. The optimal ratio of $\mathrm{H} 2 \mathrm{~S} / \mathrm{C} 3 \mathrm{~F} 8$ was found to be $2 / 2$ with the highest H2S-loading capacity. US-targeted hs-MB destruction controlled myocardial infarct sizes and also preserved left ventricular functions without any influence on hemodynamics or the respiratory system, thus leading to 
myocardial ischemia-reperfusion injury alleviation [95]. Zhu et al. tested the injection of DOX in the H22 hepatocellular carcinoma (HCC)-xenografted models combined with UTMD. Animals treated with DOX + UTMD combination had the highest tumor inhibition rate and survival rate among all tumor-burden groups $(p<0.001)$. The combination therapy of DOX + UTMD indicated improved antitumor effects for HCC and reduced the systemic side effects significantly [96].

\subsection{Stem Cell Transplantation}

Although stem cell transplantation has been applied in treatments of various diseases, its clinical application is restricted by the influence of survival rate and targeting of stem cells. To this end, US + MBs cannot only mediate the gene transfection, but also facilitate targeted delivery of transplanted cells to improve the performance of stem cell transplantation. Zhong transplanted DAPI-labeled MSCs to the myocardial infarction models by means of UTMD, and found that the expression of various cytokines in UTMD-treated animals was much higher than that observed in non-treated controls. They concluded that UTMD changes the myocardial microenvironment and promotes the homing of MSCs to the ischemic myocardium [97]. Xu established the targeted delivery of MSCs into the myocardium by using diagnostic US irradiating lipid-coated MB destruction along with bone-marrow-derived MSC infusion. The cardiac function was markedly improved and the number of capillaries was increased, whereas, the area of cardiac fibrosis was significantly decreased with US + Microbubble + MSC treatment [98]. Pu and his fellows transferred pcDNA3.1-hVEGF165 into MSCs by UTMD, and observed the effect of the protein expression. It showed that the VEGF165 protein expression increased at $24 \mathrm{~h}$ and reached the maximum level at $48 \mathrm{~h}$. Compared with the control, protein expression of the UTMD group was significantly increased. It also found that VEGF165 protein level varied to different UTMD conditions. A significant protein expression was yielded by UTMD-mediated transfection of MSCs with a mechanic index of 0.6 for $90 \mathrm{~s}$ [99].

Bone marrow stromal cell (BMSC) transplantation proves successful in treating kidney diseases. Wang et al. applied UTMD to enhance CXCR-4 transfection efficiency to improve BMSC homing to AKI kidneys, which showed the migration ability of CXCR4-modified BMSCs was 9-fold higher than controls without UTMD [100]. Wu developed SDF-1-loaded MBs (MBSDF-1) via covalent conjugation to improve MSC homing to diabetic nephropathy (DN) kidneys. SDF-1 was successfully released in the targeted kidneys in the in vivo study. The homing efficacy of MSCs to DN kidneys after the targeted release of SDF-1 was remarkably ameliorated at $24 \mathrm{~h}$ [101]. Zhang also performed UTMD to increase the renoprotective effect of kidney-targeted transplantation of bone-marrow-derived mesenchymal stem cells (BM-MSCs) in DN rats. MSCs were injected in combination with UTMD to DN rats at four weeks after diabetes onset. The results demonstrated MSC transplantation could decrease blood glucose concentrations and attenuate pancreatic islets $/ \beta$ cells damage. The permeability of renal interstitial capillaries and VCAM-1 expression increased after UTMD employment, which enhanced homing and retention of MSCs to kidneys. MSC transplantation associated with UTMD prevented renal damages and decreased albumin excretion rate (AER) values. It was concluded that UTMD non-invasively increased the homing of MSCs to kidneys and promoted renal repair in DN rats [102].

\section{Challenges and Perspectives}

Ultrasound (US) imaging is one of the most widely used medical imaging modalities in clinics, due to its advantages of non-invasiveness, ionization-free radiation, real-time availability and commercially low costs. These unique advantages and apparent potential of ultrasound differentiates it from other techniques. The introduction of multifunctional microbubbles (MBs) rejuvenates resolution with improved sensitivity and specificity. By conjugating specific ligands to the MBs to construct targeted "missiles," these MBs can be oriented to the diseased lesions with unprecedented precision. Moreover, this targeted therapy can be enhanced by carrying drugs/genes on the engineered MBs so that a combinatory strategy with both synergistic chemo-physical treatments can be implemented. 
However, the development of multifunctional MBs and the MBs + US technique are still in its infancy, and several bottleneck issues exist. For example, it is mostly used in intravascular diseases due to the micron sizes, but it is difficult to realize the investigation of a single cell or isolated tissues. Presently, nano-scaled bubbles are not well studied, and it is difficult to meet the actual requirements in this respect. Secondly, multiple targeting may offer better diagnosis than single or dual targeting. Nevertheless, it is still challenging to fabricate multifunctional MBs with better stability and prolonged circulation profiles. The limitation of real practical use of MBs in the work of Lamanauskas et al. was that sonoporation efficiency is relatively low [24]. Liu et al. analyzed 26 recent published papers and found that only a small part of the data illustrated sonoporation efficiency beyond 50\% [103]. Another common limitation was the small number of samples; more detailed studies are thus needed in future research [104].

In addition, safety evaluation is always an issue regarding the successful translation of the multifunctional MBs to humans. Future focus could emphasize the improvement of their biocompatibility and biodegradability. Potential toxicity and side effects for clinics should also be taken into consideration. In addition, secondary risks induced by US technology such as microcirculation vascular damage effect, ecchymosis and hypotension are also worthy of systematic investigations.

Although there are still a lot of areas in need of improvement, contrast agents, such as SonoVue, have been approved for human use by the FDA and are widely used for clinical examinations in China. Compared to other US, SonoVue reflects its safety in myocardial perfusion assessment, abdominal applications and transcranial ultrasound diagnostics [105-107]. The four-dimensional hysterosalpingo contrast sonography, combined with SonoVue, achieves a real-time, intuitive examination [108]. Additionally, SonoVue has recently been used to expand the yield of gene delivery. US-mediated gene delivery combined with MBs was evidenced to be significantly safer than other local gene-delivery methods [109]. The combination of US-mediated MB destruction and shRNA could enhance antitumor efficacy [110]. One study conducted by Zheng also found that SonoVue enhanced the efficiency of rAAV transfection to RPE-J cells [111].

In conclusion, the development of advanced MBs as a multifunctional platform for both imaging and therapy against diseases has shown bright perspectives in various biomedical areas. It can be expected that with the vast and portable application of ultrasound technology, the integration of "bubbles for US" will play a more active role in the future, and will serve the individualized treatments of human diseases in a more precise manner.

Acknowledgments: This study was supported by Wenzhou City Science \& Technology Bureau, China (No.Y20150084, No.Y20150085), and Health and Family Planning Commission of Zhejiang Province, China (No.2015KYA159, No.2016KYA143).

Conflicts of Interest: The authors declare no conflict of interest.

\section{References}

1. Ferrara, K.; Pollard, R.; Borden, M. Ultrasound microbubble contrast agents: Fundamentals and application to gene and drug delivery. Annu. Rev. Biomed. Eng. 2007, 9, 415-447. [CrossRef] [PubMed]

2. Gramiak, R.; Shah, P. Echocardiography of the aortic root. Investig. Radiol. 1968, 3, 356-366. [CrossRef]

3. Christian, N.; Torben, L. International guidelines for contrast-enhanced ultrasonography: Ultrasound imaging in the new millennium. Ultrasonography 2016, 35, 89-103.

4. Xie, F.; Lof, J.; Everbach, C.; He, A.; Bennett, R.M.; Matsunaga, T.; Johanning, J.; Porter, T.R. Treatment of acute intravascular thrombi with diagnostic ultrasound and intravenous microbubbles. JACC Cardiovasc. Imaging 2009, 2, 511-518. [CrossRef] [PubMed]

5. Kaneko, Y.; Maruyama, T.; Matsumoto, Y. Use of a microbubble agent to increase the effects of high intensity focused ultrasound on liver tissue. Eur. Radiol. 2005, 15, 1415-1420. [CrossRef] [PubMed]

6. Ryan, R.; Misty, L.; Carol, H. Development of Therapeutic Microbubbles for Enhancing Ultrasound-Mediated Gene Delivery. J. Control. Release 2014, 182, 111-120. 
7. Lee, H.; Yoon, Y.; Bae, Y. Theragnostic ultrasound using microbubbles in the treatment of prostate cancer. Ultrasonography 2016, 35, 309-317. [CrossRef] [PubMed]

8. Blomley, M. Which US microbubble contrast agent is best for gene therapy? Radiology 2003, 229, $297-298$. [CrossRef] [PubMed]

9. Bach, D.S. Adherence of albunex to an apical left ventricular thrombus. J. Am. Soc. Echocardiogr. 1999, 12, 761-762. [CrossRef]

10. Dolan, M.S.; Dent, J.; de Filippi, C.; Christopher, T.; Wible, J.H. Increasing the dose and rate of Albunex infusion leads to superior left ventricular contrast effect. J. Am. Soc. Echocardiogr. 1998, 11, 426-432. [CrossRef]

11. Elhendy, A.; O'Leary, E.L.; Xie, F.; McGrain, A.C.; Anderson, J.R. Comparative accuracy of real-time myocardial contrast perfusion imaging and wall motion analysis during dobutamine stress echocardiography for the diagnosis of coronary artery disease. J. Am. Coll. Cardiol. 2004, 44, 2185-2191. [CrossRef] [PubMed]

12. Elhendy, A.; Tsutsui, J.M.; O'Leary, E.L.; Xie, F.; Porter, T.R. Noninvasive diagnosis of coronary artery bypass graft disease by dobutamine stress real-time myocardial contrast perfusion imaging. J. Am. Soc. Echocardiogr. 2006, 19, 1482-1487. [CrossRef] [PubMed]

13. Jung, E.M.; Clevert, D.A.; Rupp, N. Contrast-enhanced ultrasound with Optison in percutaneous thermoablation of liver tumors. Rofo 2003, 175, 1403-1412. [PubMed]

14. Moreno, R. Usefulness of Contrast Agents in the Diagnosis of Left Ventricular Pseudoaneurysm after Acute Myocardial Infarction. Eur. J. Echocardiogr. 2002, 3, 111-116. [CrossRef] [PubMed]

15. Drelich-Zbroja, A.; Jargiello, T.; Szymanska, A.; Krzyzanowski, W.; Szczerbo-Trojanowska, M. Can Levovist-enhanced Doppler ultrasound replace angiography in abdominal branches of the aorta imaging? Ultrasound Med. Biol. 2003, 29. [CrossRef]

16. Von Herbay, A.; Haeussinger, D.; Gregor, M.; Vogt, C. Characterization and detection of hepatocellular carcinoma (HCC): Comparison of the ultrasound contrast agents SonoVue (BR1) and Levovist (SHU508A)-comparison of SonoVue and Levovist in HCC. Ultraschall Med. 2007, 28, 168-175. [CrossRef] [PubMed]

17. Rubiera, M.; Ribo, M.; Delgado-Mederos, R.; Santamarina, E.; Maisterra, O. Do bubble characteristics affect recanalization in stroke patients treated with microbubble-enhanced sonothrombolysis? Ultrasound Med. Biol. 2008, 34, 1573-1577. [CrossRef] [PubMed]

18. Hoffmann, R.; von Bardeleben, S.; Barletta, G.; Pasques, A.; Kasprzak, J. Comparison of two- and three-dimensional unenhanced and contrast-enhanced echocardiographies versus cineventriculography versus cardiac magnetic resonance for determination of left ventricular function. Am. J. Cardiol. 2014, 113, 395-401. [CrossRef] [PubMed]

19. Liu, X.; Yang, Y.L.; Sun, S.G.; Yang, R.J.; Wang, J. A new method of measurement of cerebral circulation time: Contrast-enhanced ultrasonography in healthy adults and patients with intracranial shunts. Ultrasound Med. Biol. 2014, 40, 2372-2378. [CrossRef] [PubMed]

20. Cai, W.B.; Yang, H.L.; Zhang, J.; Yin, J.K.; Yang, Y.L. The Optimized Fabrication of Nanobubbles as Ultrasound Contrast Agents for Tumor Imaging. Sci. Rep. 2015, 5. [CrossRef] [PubMed]

21. Iezzi, R.; Petrone, G.; Ferrante, A.; Lauriola, L.; Vincenzoni, C. The role of contrast-enhanced ultrasound (CEUS) in visualizing atherosclerotic carotid plaque vulnerability: Which injection protocol? Which scanning technique? Eur. J. Radiol. 2015, 84, 865-871. [CrossRef] [PubMed]

22. Dong, Y.; Mao, F.; Wang, W.P.; Ji, Z.B.; Fan, P.L. Value of Contrast-Enhanced Ultrasound in Guidance of Percutaneous Biopsy in Peripheral Pulmonary Lesions. Biomed. Res. Int. 2015, 2015. [CrossRef] [PubMed]

23. Li, H.; Wan, C.; Du, L.; Li, F. Enhanced downregulation of transforming growth factorbeta2 in rat retinal pigment epithelium cells by adenoassociated virusmediated ribonucleic acid interference combined with ultrasound or microbubbles. Mol. Med. Rep. 2015, 11, 1099-1104. [PubMed]

24. Lamanauskas, N.; Novell, A.; Escoffre, J.M.; Venslauskas, M.; Satkauskas, S. Bleomycin delivery into cancer cells in vitro with ultrasound and SonoVue(R) or BR14(R) microbubbles. J. Drug Target 2013, 21, 407-414. [CrossRef] [PubMed]

25. Nacu, A.; Kvistad, C.E.; Logallo, N.; Naess, H.; Waje-Andreassen, U. A pragmatic approach to sonothrombolysis in acute ischaemic stroke: The Norwegian randomised controlled sonothrombolysis in acute stroke study (NOR-SASS). BMC Neurol. 2015, 15. [CrossRef] [PubMed]

26. Rotaru, L.; Nanea, T. Assessment of myocardial perfusion using contrast echocardiography-Case report. J. Med. Life 2015, 8, 471-475. [PubMed] 
27. Porter, T.R.; Adolphson, M.; High, R.R.; Smith, L.M.; Olson, J. Rapid detection of coronary artery stenoses with real-time perfusion echocardiography during regadenoson stress. Circ. Cardiovasc. Imaging 2011, 4, 628-635. [CrossRef] [PubMed]

28. Hoyt, K.; Umphrey, H.; Lockhart, M.; Robbin, M.; Forero-Torres, A. Ultrasound imaging of breast tumor perfusion and neovascular morphology. Ultrasound Med. Biol. 2015, 41, 2292-2302. [CrossRef] [PubMed]

29. Sun, R.R.; Noble, M.L.; Sun, S.S.; Song, S.; Miao, C.H. Development of therapeutic microbubbles for enhancing ultrasound-mediated gene delivery. J. Control. Release 2014, 182, 111-120. [CrossRef] [PubMed]

30. Datta, S.; Coussios, C.C.; Ammi, A.Y.; Mast, T.D.; de Courten-Myers, G.M. Ultrasound-enhanced thrombolysis using Definity as a cavitation nucleation agent. Ultrasound Med. Biol. 2008, 34, 1421-1433. [CrossRef] [PubMed]

31. Kudo, M. Diagnostic Imaging of Hepatocellular Carcinoma: Recent Progress. Oncology 2011, 81, 73-85. [CrossRef] [PubMed]

32. Miyamoto, Y.; Ito, T.; Takada, E.; Omoto, K.; Hirai, T.; Moriyasu, F. Effcacy of Sonazoid (Perflubutane) for Contrast-Enhanced Ultrasound in the Differentiation of Focal Breast Lesions: Phase 3 Multicenter Clinical Trial. Am. J. Roentgenol. 2014, 202, W400-W407. [CrossRef] [PubMed]

33. Yan, F.; Xu, X.; Chen, Y.; Deng, Z.; Liu, H. A Lipopeptide-Based alphavbeta(3) Integrin-Targeted Ultrasound Contrast Agent for Molecular Imaging of Tumor Angiogenesis. Ultrasound Med. Biol. 2015, 41, 2765-2773. [CrossRef] [PubMed]

34. Nascimento, T.L.; Rosa, P.; Soletti, R.C.; Borges, H.L.; Machado, J.C. Contrast-Enhanced Images of Endoluminal Ultrasound Biomicroscopy from Mouse Colorectal Tumors Using VEGFR2-Targeted Contrast Agents. Ultrasound Med. Biol. 2013, 39, S15-S16. [CrossRef]

35. Wei, S.; Fu, N.; Sun, Y.; Yang, Z.; Lei, L. Targeted contrast-enhanced ultrasound imaging of angiogenesis in an orthotopic mouse tumor model of renal carcinoma. Ultrasound Med. Biol. 2014, 40, 1250-1259. [CrossRef] [PubMed]

36. Pillai, R.; Marinelli, E.R.; Fan, H.; Nanjappan, P.; Song, B.; von Wronski, M.A.; Cherkaoui, S.; Tardy, I.; Pochon, S.; Schneider, M.; et al. A phospholipid-PEG2000 conjugate of a vascular endothelial growth factor receptor 2 (VEGFR2)-targeting heterodimer peptide for contrast-enhanced ultrasound imaging of angiogenesis. Bioconjug. Chem. 2010, 21, 556-562. [CrossRef] [PubMed]

37. Sorace, A.G.; Saini, R.; Mahoney, M.; Hoyt, K. Molecular ultrasound imaging using a targeted contrast agent for assessing early tumor response to antiangiogenic therapy. J. Ultrasound Med. 2012, 31, 1543-1550. [PubMed]

38. Bachawal, S.V.; Jensen, K.C.; Wilson, K.E.; Tian, L.; Lutz, A.M. Breast Cancer Detection by B7H3-Targeted Ultrasound Molecular Imaging. Cancer Res. 2015, 75, 2501-2509. [CrossRef] [PubMed]

39. Tsuruta, J.K.; Klauber-DeMore, N.; Streeter, J.; Samples, J.; Patterson, C. Ultrasound molecular imaging of secreted frizzled related protein-2 expression in murine angiosarcoma. PLoS ONE 2014, 9, e86642. [CrossRef] [PubMed]

40. Hu, Q.; Wang, X.; Kang, L.; Wei, H.; Xu, C. RGD-Targeted Ultrasound Contrast Agent for Longitudinal Assessment of Hep2 Tumor Angiogenesis In Vivo. PLoS ONE 2016, 11, e0149075.

41. Mai, L.; Yao, A.; Li, J.; Wei, Q.; Yuchi, M. Cyanine5.5 conjugated nanobubbles as a tumor selective contrast agent for dual ultrasound-fluorescence imaging in a mouse model. PLoS ONE 2013, 8, e61224. [CrossRef] [PubMed]

42. Kim, M.; Lee, J.H.; Kim, S.E.; Kang, S.S.; Tae, G. Nanosized Ultrasound Enhanced-Contrast Agent for in Vivo Tumor Imaging via Intravenous Injection. ACS Appl. Mater. Interfaces 2016, 8, 8409-8418. [CrossRef] [PubMed]

43. Yang, H.; Cai, W.; Xu, L.; Lv, X.; Qiao, Y. Nanobubble-Affibody: Novel ultrasound contrast agents for targeted molecular ultrasound imaging of tumor. Biomaterials 2015, 37, 279-288. [CrossRef] [PubMed]

44. Hu, Y.; Wang, Y.; Jiang, J.; Han, B.; Zhang, S. Preparation and Characterization of Novel Perfluorooctyl Bromide Nanoparticle as Ultrasound Contrast Agent via Layer-by-Layer Self-Assembly for Folate-Receptor-Mediated Tumor Imaging. Biomed. Res. Int. 2016, 2016. [CrossRef] [PubMed]

45. Pysz, M.A.; Foygel, K.; Rosenberg, J.; Gambhir, S.S.; Schneider, M.; Willmann, J.K. Antiangiogenic cancer therapy: Monitoring with molecular US and a clinically translatable contrast agent (BR55). Radiology 2010, 256, 519-527. [CrossRef] [PubMed] 
46. Pochon, S.; Tardy, I.; Bussat, P.; Bettinger, T.; Brochot, J.; von, W.M.; Passantino, L.; Schneider, M. BR55: A lipopeptide-based VEGFR2-targeted ultrasound contrast agent for molecular imaging ofangiogenesis. Investig. Radiol. 2010, 45, 89-95. [CrossRef] [PubMed]

47. Bzyl, J.; Lederle, W.; Rix, A.; Grouls, C.; Tardy, I.; Pochon, S.; Siepmann, M.; Penzkofer, T.; Schneider, M.; Kiessling, F. Molecular and functional ultrasound imaging in differently aggressive breast cancer xenografts using two novel ultrasound contrast agents (BR55 and BR38). Eur. Radiol. 2011, 21, 1988-1995. [CrossRef] [PubMed]

48. Tardy, I.; Pochon, S.; Theraulaz, M.; Emmel, P.; Passantino, L.; Tranquart, F.; Schneider, M. Ultrasound molecular imaging of VEGFR2 in a rat prostate tumor model using BR55. Investig. Radiol. 2010, 45, 573-578. [CrossRef] [PubMed]

49. Lee, D.J.; Lyshchik, A.; Huamani, J.; Hallahan, D.E.; Fleischer, A.C. Relationship between retention of a vascular endothelial growth factor receptor 2 (VEGFR2)-targeted ultrasonographic contrast agent and the level of VEGFR2 expression in an in vivo breast cancer model. J. Ultrasound Med. 2008, 27, 855-866. [PubMed]

50. Korpanty, G.; Carbon, J.G.; Grayburn, P.A.; Fleming, J.B.; Brekken, R.A. Monitoring response to anticancer therapy by targeting microbubbles to tumor vasculature. Clin. Cancer Res. 2007, 13, 323-330. [CrossRef] [PubMed]

51. Willmann, J.K.; Paulmurugan, R.; Chen, K.; Gheysens, O.; Rodriguez-Porcel, M.; Lutz, A.M.; Chen, I.Y.; Chen, X.; Gambhir, S.S. US imaging of tumor angiogenesis with microbubbles targeted to vascular endothelial growth factor receptor type 2 in mice. Radiology 2008, 246, 508-518. [CrossRef] [PubMed]

52. Palmowski, M.; Huppert, J.; Ladewig, G.; Hauff, P.; Reinhardt, M.; Mueller, M.M.; Woenne, E.C.; Jenne, J.W.; Maurer, M.; Kauffmann, G.W. Molecular profiling of angiogenesis with targeted ultrasound imaging: Early assessment of antiangiogenic therapy effects. Mol. Cancer Ther. 2008, 7, 101-109. [CrossRef] [PubMed]

53. Ellegala, D.B.; Leong-Poi, H.; Carpenter, J.E.; Klibanov, A.L.; Kaul, S.; Shaffrey, M.E.; Sklenar, J.; Lindner, J.R. Imaging tumor angiogenesis with contrast ultrasound and microbubbles targeted to alpha(v)beta3. Circulation 2003, 108, 336-341. [CrossRef] [PubMed]

54. Willmann, J.K.; Kimura, R.H.; Deshpande, N.; Lutz, A.M.; Cochran, J.R.; Gambhir, S.S. Targeted contrast-enhanced ultrasound imaging of tumor angiogenesis with contrast microbubbles conjugated to integrin-binding knottin peptides. J. Nucl. Med. 2010, 51, 433-440. [CrossRef] [PubMed]

55. Deshpande, N.; Ren, Y.; Foygel, K.; Rosenberg, J.; Willmann, J.K. Tumor angiogenic marker expression levels during tumor growth: Longitudinal assessment with molecularly targeted microbubbles and US imaging. Radiology 2011, 258, 804-811. [CrossRef] [PubMed]

56. Palmowski, M.; Peschke, P.; Huppert, J.; Hauff, P.; Reinhardt, M.; Maurer, M.; Karger, C.P.; Scholz, M.; Semmler, W.; Huber, P.E. Molecular ultrasound imaging of early vascular response in prostate tumors irradiated with carbon ions. Neoplasia 2009, 11, 856-863. [CrossRef] [PubMed]

57. Willmann, J.K.; Lutz, A.M.; Paulmurugan, R.; Patel, M.R.; Chu, P.; Rosenberg, J.; Gambhir, S.S. Dual-targeted contrast agent for US assessment of tumor angiogenesis in vivo. Radiology 2008, 248, 936-944. [CrossRef] [PubMed]

58. Warram, J.M.; Sorace, A.G.; Saini, R.; Umphrey, H.R.; Zinn, K.R.; Hoyt, K. A triple-targeted ultrasound contrast agent provides improved localization to tumor vasculature. J. Ultrasound Med. 2011, 30, 921-931. [PubMed]

59. Zhang, H.; Tam, S.; Ingham, E.S.; Mahakian, L.M.; Lai, C.Y.; Tumbale, S.K.; Teesalu, T.; Hubbard, N.E.; Borowsky, A.D.; Ferrara, K.W. Ultrasound molecular imaging of tumor angiogenesis with a neuropilin-1-targeted microbubble. Biomaterials 2015, 56, 104-113. [CrossRef] [PubMed]

60. Bettinger, T.; Bussat, P.; Tardy, I.; Pochon, S.; Hyvelin, J.M. Ultrasound molecular imaging contrast agent binding to both E- and P-selectin in different species. Investig. Radiol. 2012, 47, 516-523. [CrossRef] [PubMed]

61. Wang, H.; Machtaler, S.; Bettinger, T.; Lutz, A.; Luong, R. Molecular imaging of inflammation in inflammatory bowel disease with a clinically translatable dual-selectin-targeted US contrast agent: Comparison with FDG PET/CT in a mouse model. Radiology 2013, 267, 818-829. [CrossRef] [PubMed]

62. Machtaler, S.; Knieling, F.; Luong, R.; Tian, L.; Willmann, J.K. Assessment of Inflammation in an Acute on Chronic Model of Inflammatory Bowel Disease with Ultrasound Molecular Imaging. Theranostics 2015, 5, 1175-1186. [CrossRef] [PubMed] 
63. Hoyt, K.; Warram, J.M.; Wang, D.; Ratnayaka, S.; Traylor, A. Molecular Ultrasound Imaging of Tissue Inflammation Using an Animal Model of Acute Kidney Injury. Mol. Imaging Biol. 2015, 17, 786-792. [CrossRef] [PubMed]

64. Weller, G.E.; Lu, E.; Csikari, M.M.; Klibanov, A.L.; Fischer, D. Ultrasound imaging of acute cardiac transplant rejection with microbubbles targeted to intercellular adhesion molecule-1. Circulation 2003, 108, 218-224. [CrossRef] [PubMed]

65. Hagisawa, K.; Nishioka, T.; Suzuki, R.; Takizawa, T.; Maruyama, K. Enhancement of ultrasonic thrombus imaging using novel liposomal bubbles targeting activated platelet glycoprotein IIb/IIIa complex-in vitro and in vivo study. Int. J. Cardiol. 2011, 152, 202-206. [CrossRef] [PubMed]

66. Hu, G.; Liu, C.; Liao, Y.; Yang, L.; Huang, R. Ultrasound molecular imaging of arterial thrombi with novel microbubbles modified by cyclic RGD in vitro and in vivo. Thromb. Haemost. 2012, 107, 172-183. [CrossRef] [PubMed]

67. Hyvelin, J.M.; Tardy, I.; Bettinger, T.; von Wronski, M.; Costa, M. Ultrasound molecular imaging of transient acute myocardial ischemia with a clinically translatable P- and E-selectin targeted contrast agent: Correlation with the expression of selectins. Investig. Radiol. 2014, 49, 224-235. [CrossRef] [PubMed]

68. Hynynen, K.; McDannold, N.; Vykhodtseva, N.; Jolesz, F.A. Noninvasive MR imaging-guided focal opening of the blood-brain barrier in rabbits. Radiology 2001, 220, 640-646. [CrossRef] [PubMed]

69. Burgess, A.; Hynynen, K. Noninvasive and targeted drug delivery to the brain using focused ultrasound. ACS Chem. Neurosci. 2013, 4, 519-526. [CrossRef] [PubMed]

70. Mooney, S.J.; Shah, K.; Yeung, S.; Burgess, A.; Aubert, I. Focused Ultrasound-Induced Neurogenesis Requires an Increase in Blood-Brain Barrier Permeability. PLoS ONE 2016, 11, e0159892. [CrossRef] [PubMed]

71. Kobus, T.; Zervantonakis, I.K.; Zhang, Y.; McDannold, N.J. Growth inhibition in a brain metastasis model by antibody delivery using focused ultrasound-mediated blood-brain barrier disruption. J. Control. Release 2016, 238, 281-288. [CrossRef] [PubMed]

72. Lelu, S.; Afadzi, M.; Berg, S.; Aslund, A.; Torp, S. Primary porcine brain endothelial cells as in vitro model to study effects of ultrasound on blood-brain barrier function. IEEE Trans. Ultrason. Ferroelectr. Freq. Control 2016. [Epub ahead of print]. [CrossRef] [PubMed]

73. Fan, C.H.; Chang, E.L.; Ting, C.Y.; Lin, Y.C.; Liao, E.C. Folate-conjugated gene-carrying microbubbles with focused ultrasound for concurrent blood-brain barrier opening and local gene delivery. Biomaterials 2016, 106, 46-57. [CrossRef] [PubMed]

74. Samiotaki, G.; Acosta, C.; Wang, S.; Konofagou, E.E. Enhanced delivery and bioactivity of the neurturin neurotrophic factor through focused ultrasound-mediated blood-brain barrier opening in vivo. J. Cereb. Blood Flow Metab. 2015, 35, 611-622. [CrossRef] [PubMed]

75. Lin, C.Y.; Hsieh, H.Y.; Chen, C.M.; Wu, S.R.; Tsai, C.H. Non-invasive, neuron-specific gene therapy by focused ultrasound-induced blood-brain barrier opening in Parkinson's disease mouse model. J. Control. Release 2016, 235, 72-81. [CrossRef] [PubMed]

76. Leinenga, G.; Gotz, J. Scanning ultrasound removes amyloid-beta and restores memory in an Alzheimer's disease mouse model. Sci. Transl. Med. 2015, 7, 278ra233. [CrossRef] [PubMed]

77. Aryal, M.; Vykhodtseva, N.; Zhang, Y.Z.; Park, J.; McDannold, N. Multiple treatments with liposomal doxorubicin and ultrasound-induced disruption of blood-tumor and blood-brain barriers improve outcomes in a rat glioma model. J. Control. Release 2013, 169, 103-111. [CrossRef] [PubMed]

78. Underwood, E. Can sound open the brain for therapies? Science 2015, 347, 1186-1187. [CrossRef] [PubMed]

79. Carpentier, A.; Canney, M.; Vignot, A.; Reina, V.; Beccaria, K. Clinical trial of blood-brain barrier disruption by pulsed ultrasound. Sci. Transl. Med. 2016, 8, 343re342. [CrossRef] [PubMed]

80. Trubestein, G.; Engel, C.; Etzel, F.; Sobbe, A.; Cremer, H. Thrombolysis by ultrasound. Clin. Sci. Mol. Med. Suppl. 1976, 3, 697s-698s. [CrossRef] [PubMed]

81. Tachibana, K.; Tachibana, S. Albumin Microbubble Echo-Contrast Material as an Enhancer for Ultrasound Accelerated Thrombolysis. Circulation 1995, 92, 1148-1150. [CrossRef] [PubMed]

82. Roessler, F.C.; Wang, Z.; Schumacher, S.; Ohlrich, M.; Kaps, M. In Vitro Examination of the Thrombolytic Efficacy of Desmoteplase and Therapeutic Ultrasound Compared with rt-PA. Ultrasound Med. Biol. 2015, 41, 3233-3240. [CrossRef] [PubMed] 
83. Schleicher, N.; Tomkins, A.J.; Kampschulte, M.; Hyvelin, J.M.; Botteron, C. Sonothrombolysis with BR38 Microbubbles Improves Microvascular Patency in a Rat Model of Stroke. PLoS ONE 2016, 11, e0152898. [CrossRef] [PubMed]

84. Petit, B.; Yan, F.; Bussat, P.; Bohren, Y.; Gaud, E. Fibrin degradation during sonothrombolysis- Effect of ultrasound, microbubbles and tissue plasminogen activator. J. Drug Deliv. Sci. Technol. 2015, 25, 29-35. [CrossRef]

85. Lu, Y.; Wang, J.; Huang, R.; Chen, G.; Zhong, L. Microbubble-Mediated Sonothrombolysis Improves Outcome after Thrombotic Microembolism-Induced Acute Ischemic Stroke. Stroke 2016, 47, 1344-1353. [CrossRef] [PubMed]

86. McCabe, J.M.; Huang, P.H.; Riedl, L.; Eisenhauer, A.C.; Sobieszczyk, P. Usefulness and safety of ultrasound-assisted catheter-directed thrombolysis for submassive pulmonary emboli. Am. J. Cardiol. 2015, 115, 821-824. [CrossRef] [PubMed]

87. Vancraeynest, D.; Havaux, X.; Pouleur, A.; Pasquet, A.; Gerber, B. Myocardial delivery of colloid nanoparticles using ultrasound-targeted microbubble destruction. Eur. Heart J. 2006, 27, 237-245. [CrossRef] [PubMed]

88. Zhao, Y.Z.; Lu, C.T.; Li, X.K.; Tang, Q.Q.; Tian, X.Q. Improving the cardio protective effect of aFGF in ischemic myocardium with ultrasound-mediated cavitation of heparin modified microbubbles: Preliminary experiment. J. Drug Target 2012, 20, 623-631. [CrossRef] [PubMed]

89. Fujii, H.; Li, S.H.; Wu, J.; Miyagi, Y.; Yau, T.M. Repeated and targeted transfer of angiogenic plasmids into the infarcted rat heart via ultrasound targeted microbubble destruction enhances cardiac repair. Eur. Heart J. 2011, 32, 2075-2084. [CrossRef] [PubMed]

90. Liao, A.H.; Chung, H.Y.; Chen, W.S.; Yeh, M.K. Efficacy of Combined Ultrasound-and-MicrobubblesMediated Diclofenac Gel Delivery to Enhance Transdermal Permeation in Adjuvant-Induced Rheumatoid Arthritis in the Rat. Ultrasound Med. Biol. 2016, 42, 1976-1985. [CrossRef] [PubMed]

91. Xiang, X.; Tang, Y.; Leng, Q.; Zhang, L.; Qiu, L. Targeted gene delivery to the synovial pannus in antigen-induced arthritis by ultrasound-targeted microbubble destruction in vivo. Ultrasonics 2016, 65, 304-314. [CrossRef] [PubMed]

92. Zhang, X.; Zhao, K.; Wang, J.; Bai, S.; Jiao, S. Design of simvastatin-loaded polymeric microbubbles as targeted ultrasound contrast agents for vascular imaging and drug delivery in the identification of atherosclerotic plaque. New J. Chem. 2016, 40, 1256-1262. [CrossRef]

93. Chertok, B.; Langer, R.; Anderson, D.G. Spatial Control of Gene Expression by Nanocarriers Using Heparin Masking and Ultrasound-Targeted Microbubble Destruction. ACS Nano 2016, 10, 7267-7278. [CrossRef] [PubMed]

94. Chung, Y.H.; Hsu, P.H.; Huang, C.W.; Hsieh, W.C.; Huang, F.T.; Chang, W.C.; Chiu, H.; Hsu, S.T.; Yen, T.C. Evaluation of prognostic integrin $\alpha 2 \beta 1$ PET tracer and concurrent targeting delivery using focused ultrasound for brain glioma detection. Mol. Pharm. 2014, 11, 3904-3914. [CrossRef] [PubMed]

95. Chen, G.; Yang, L.; Zhong, L.; Kutty, S.; Wang, Y. Delivery of Hydrogen Sulfide by Ultrasound Targeted Microbubble Destruction Attenuates Myocardial Ischemia-reperfusion Injury. Sci. Rep. 2016, 6. [CrossRef] [PubMed]

96. Zhu, F.; Jiang, Y.; Luo, F.; Li, P. Effectiveness of localized ultrasound-targeted microbubble destruction with doxorubicin liposomes in H22 mouse hepatocellular carcinoma model. J. Drug Target 2015, 23, 323-334. [CrossRef] [PubMed]

97. Zhong, S.; Shu, S.; Wang, Z.; Luo, J.; Zhong, W. Enhanced homing of mesenchymal stem cells to the ischemic myocardium by ultrasound-targeted microbubble destruction. Ultrasonics 2012, 52, 281-286. [CrossRef] [PubMed]

98. Xu, Y.L.; Gao, Y.H.; Liu, Z.; Tan, K.B.; Hua, X. Myocardium-targeted transplantation of mesenchymal stem cells by diagnostic ultrasound-mediated microbubble destruction improves cardiac function in myocardial infarction of New Zealand rabbits. Int. J. Cardiol. 2010, 138, 182-195. [CrossRef] [PubMed]

99. Pu, Z.; You, X.; Xu, Q.; Gao, F.; Xie, X. Protein expression of mesenchymal stem cells after transfection of pcDNA3.1--hVEGF 165 by ultrasound-targeted microbubble destruction. J. Biomed. Biotechnol. 2011, 2011. [CrossRef] [PubMed]

100. Wang, G.; Zhang, Q.; Zhuo, Z.; Wu, S.; Xu, Y. Enhanced Homing of CXCR-4 Modified Bone Marrow-Derived Mesenchymal Stem Cells to Acute Kidney Injury Tissues by Micro-Bubble-Mediated Ultrasound Exposure. Ultrasound Med. Biol. 2016, 42, 539-548. [CrossRef] [PubMed] 
101. Wu, S.; Li, L.; Wang, G.; Shen, W.; Xu, Y. Ultrasound-targeted stromal cell-derived factor-1-loaded microbubble destruction promotes mesenchymal stem cell homing to kidneys in diabetic nephropathy rats. Int. J. Nanomed. 2014, 9, 5639-5651.

102. Zhang, Y.; Ye, C.; Wang, G.; Gao, Y.; Tan, K. Kidney-targeted transplantation of mesenchymal stem cells by ultrasound-targeted microbubble destruction promotes kidney repair in diabetic nephropathy rats. Biomed. Res. Int. 2013, 2013. [CrossRef] [PubMed]

103. Liu, Y.; Yan, J.; Prausnitz, M.R. Can ultrasound enable efficient intracellular uptake of molecules? A retrospective literature review and analysis. Ultrasound Med. Biol. 2012, 38, 876-888. [CrossRef] [PubMed]

104. Wang, J.; Zhou, D.; Xie, X.; Shen, P.; Zeng, Y. Utility of contrast-enhanced ultrasound with SonoVue in biopsy of small subpleural nodules. Int. J. Clin. Exp. Med. 2015, 8, 15991-15998. [PubMed]

105. Dijkmans, P.A.; Juffermans, L.J.; van Dijk, J.; Musters, R.J.P.; Spreeuwenberg, M.D.; Kamp, O. Safety and feasibility of real time adenosine myocardial contrast echocardiography with emphasis on induction of arrhythmias: A study in healthy volunteers and patients with stable coronary artery disease. Echocardiography 2009, 26, 807-814. [CrossRef] [PubMed]

106. Beaton, C.; Cochlin, D.; Kumar, N. Contrast enhanced ultrasound should be the initial radiological investigation to characterize focal liver lesions. Eur. J. Surg. Oncol. 2010, 36, 43-46. [CrossRef] [PubMed]

107. Kaps, M.; Seidel, G.; Bokor, D.; Modrau, B.; Algermissern, C. Safety and ultrasound-enhancing potentials of a new sulfur hexafluoride-containing agent in the cerebral circulation. J. Neuroimaging 1999, 9, 150-154. [CrossRef] [PubMed]

108. Zhou, L.; Zhang, X.; Chen, X.; Liao, L.; Pan, R.; Zhou, N.; Di, N. Value of three-dimensional hystero-Salpingocontrast sonography with SonoVue in the assessment of tubal patency. Ultrasound Obstet. Gynecol. 2012, 40, 93-98. [CrossRef] [PubMed]

109. Yoon, C.S.; Park, J.H. Ultrasound-mediated gene delivery. Expert Opin. Drug. Deliv. 2010, 7, 321-330. [CrossRef] [PubMed]

110. Chen, Z.; Liang, K.; Xie, M.; Wang, X.; Lü, Q.; Zhang, J. Induced apoptosis with ultrasound-mediated microbubble destruction and shRNA targeting survivin in transplanted tumors. Adv. Ther. 2009, 26, 99-106. [CrossRef] [PubMed]

111. Zheng, X.Z.; Li, H.L.; Du, L.F.; Wang, H.P.; Gu, Q. Comparative analysis of gene transfer to human and rat retinal pigment epithelium cell line by a combinatorial use of recombinant adeno-associated virus and ultrasound or/and microbubbles. Bosn. J. Basic Med. Sci. 2009, 9, 174-181. [PubMed] 